\title{
КОНЦЕПЦИЯ ЕДИНОГО НАЛОГООБЛОЖЕНИЯ И ЕЕ РАЗВИТИЕ В УКРАИНЕ
}

Аннотация. В статье рассматривается концепция единого налогообложения, анализируются подходы ученых к данной концепции, которые формировались на протяжении нескольких столетий, выявляются сущностные черты единого налогообложения. Отдельное внимание обрашается на развитие правового регулирования единого налога с момента обретения Украиной независимости. Исследуются современные тенденции относительно развития налогового законодательства, констатируется собственное видение состояния правового регулирования отдельных элементов единого налога и предлагаются собственные выводы относительно иелесообразности внесения изменений по поводу усовершенствования налогового законодательства. Решить теоретические и практические задачи, которые автор статьи поставил перед собой, помогла совокупность общих и специиальных методов познания. Так, среди общенаучных для изучения проблематики были выбраны следующие: диалектический метод, метод системного анализа, логический метод. Также использовались следующие специильные методы: системно-функииональный, толкования правовых норм, сравнительно-правовой. Усовершенствованы знания о правовом регулировании взымания единого налога в Украине. В исследовании проанализировано развитие налогового законодательства, регулирующего упрощенную систему налогообложения, учета и отчетности субъектов малого предпринимательства. Получило дальнейшее развитие изучение изменений, которые произошли в законодательном регулировании взимания единого налога с вступлением в силу главы 1 раздела 14 Налогового кодекса Украины, а также определены направления совершенствования налогового законодательства.

Ключевые слова: налогообложение, режим, налоговый режим, специальный налоговый режим, единый налог, налоговое законодательство, налоговая обязанность, правовое регулирование, упрощенная система, принцип налогообложения.

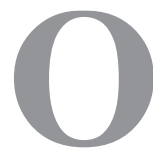

тношения налогообложения всегда характеризовались динамичностью и изменчивостью. Такое положение дел нельзя назвать оптимальным для привлечения инвестиций в национальную экономику, ведь именно в стабильности и прозрачности правового регулирования налогообложения заинтересованные инвесторы. Вместе с тем, сложно переоценить важность формирования эффективной и действенной системы налогообложения, что в условиях постепенного перехода от командно-админи- стративной системы к свободной экономике производится, в частности, путем постоянного усовершенствования и согласования норм, которыми регулируются отношения по поводу налогообложения. При этом имеем заметить, что развитие малого и среднего бизнеса, как свидетельствует практика развитых стран, как раз и становится той крепкой основой, на которую может опираться национальная экономика. Налогообложение в рамках данной модели целесообразно проводить с применением специальных налого- 
вых режимов, одним из которых выступает «единый налог».

История становления единого налога не ограничивается историческим обретением Украиной независимости в 1991 году. Еще в начале XX ст. Е. Селигман предложил теорию единого подоходного налога. [13] ${ }^{1}$ По его мнению такая конструкция должна была заменить все прямые налоги, что привело к критике со стороны других научных работников того времени. Например, А. Исаев подчеркивал, что единый подоходный налог может быть только фикцией, поскольку он делится на целый ряд подоходных налогов: поземельный, подомовой, промышленный и т. п. $[3]^{2}$ и приводил ряд аргументов по поводу невозможности введения единого подоходного налога на практике. $[15,12]^{3}$ На наш взгляд, с такой категоричной позицией едва ли можно согласиться в современных условиях.

Теории единого налога уделял внимание Н.В. Миляков, который подходит к единому налогу как к единственному, исключительному налогу на один определенный объект налогообложения. Ученый подчеркивает, что в качестве единого объекта налогообложения различными теоретиками предлагались земля, расходы, недвижимость, доход, капитал и др. По мнению ученого, ввиду развития налогово-правовой науки, сейчас теория единого налога используется как методологическая основа достижения простоты налоговой сис-

\footnotetext{
${ }^{1}[13]$ Селигман Э. Этюды по теории обложения / Селигман Э., Стурм Р.—СПб.: Тип. Правда, 1908.—200 c. - C. 98 .

2 [3] Исаев А. Л. Начала политической экономии / Исаев А. Л.-СПб.: Тип. Стасюлевича, 1896.- С. 75.

$3[15,12]$ Финансы и налоги: очерки теории и политики. - М.: Статут (в серии «Золотые страницы финансового права России»), 2004.— Т. 4.- С. 569; Пушкарева В. М. История финансовой мысли и политики налогов / В. М. Пушкарева.- М.: ИНФРА-М, 1996.- 192 c.- C. 115.
}

темы. «Объективные исследователи используют аппарат этой теории не для построения единственного налога, а для конструирования эффективной, простой налоговой системы с оптимальным количеством составляющих ее налогов.» $[6]^{4}$

Несколько иначе подходит к теории единого налогообложения М.А. Пожидаева, по мнению которой в основе любой из теорий единого налога заложено, что налоги в конечном результате платятся с одного источника - доходов. Ученая подчеркивает, что в таком случае единый налог представляется более целесообразным, простейшим способом налогообложения доходов, чем множество отдельных налогов. [9] ${ }^{5}$ Сходное мнение можно найти в работах А.А. Соколова, который утверждал, что национальный доход, будучи макроэкономической формой чистого дохода общества, выступает этим единственным или почти единственным источником взимания. «Но раз у нас имеется только один или почти один источник, то, естественно, возникает вопрос, не является ли эта множественность налогов излишним нагромождением налоговых форм, от которого мы без ущерба или даже с пользой для дела могли бы отказаться, заменив все это разнообразие налогов какимлибо единым налогом». [14] ${ }^{6}$

С этим тяжело однозначно согласиться, ведь, как отмечалось раньше, источником налога может быть не только доход. Более детальное ознакомление с работами указанных ученых наводит на мысль, что национальный

\footnotetext{
${ }^{4}$ [6] Миляков Н. В. Налоговое право: Учебник / Н. В. Миляков. - М.: ИНФРА-М, 2008. - 383 с.

${ }^{5}$ [9] Пожидаєва М. А. Правове регулювання єдиного податку для суб’єктів малого підприємництва: Дис... канд. юрид. наук: 12.00.07 / М. А. Пожидаєва; НАН України. Ін-т держави і права ім. В. М. Корецького.-К., 2005.- 204 c. - C. 13.

${ }^{6}[14]$ Соколов А. А. Теория налогов / А. А. Соколов. М.: ООО «ЮрИнфоР-Пресс», 2003.— С. 121.
} 
доход представляет собой теоретическую конструкцию, тогда как на практике налоговые поступления происходят от различных объектов, которые в итоге приносят доход. «Доход приносят земля, дома, промыслы и др. Национальный доход теоретически один, но конкретно он проявляется в различных формах, оседая около не одного, а многих объектов. Вот почему нельзя приурочить все обложение к какому-либо одному из доходоприносящих объектов, так как ни один из них не позволяет охватить всего национального дохода в целом. Множественность доходоприносящих объектов приводит к множественности налогов.». [6] $]^{1}$

Следует согласиться с М.А. Пожидаевой относительно несовершенства существующих ранее теорий единого налога ввиду предложения единого объекта налогообложения для всех плательщиков без учета развития дифференциации национального дохода. При этом также нарушался принцип равномерности налогообложения, что делало невозможным реализацию теории единого налога на практике. [9] ${ }^{2}$ Вместе с тем, все теории единого налога были направлены на упрощения системы налогообложения. Такой подход остался и сейчас, что способствует уменьшению налоговой нагрузки, сокращению расходов на взыскание налогов, стимулированию развития предпринимательской активности населения.

Не смотря на это, все же следует учитывать неравномерность объекта налогообложения, различный режим источников налога. Различные доходоприносящие источники, как

\footnotetext{
1 [6] Миляков Н. В. Налоговое право: Учебник / Н. В. Миляков. - М.: ИНФРА-М, 2008. - 383 с.- С. 358-359.

2 [9] Пожидаєва М. А. Правове регулювання єдиного податку для суб'єктів малого підприємництва: Дис... канд. юрид. наук: 12.00.07 / М. А. Пожидаєва; НАН України. Ін-т держави і права ім. В. М. Корецького.-К., 2005.204 c. - C. 11-16.
}

уже говорилось ранее, во многом определяют множественность налогов, что уверенно доказывает современное правовое регулирование отношений налогообложения. Вместе с тем, анализ становления правового регулирования единого налога свидетельствует о существовании периодов, представления о единственном налоге признавались наиболее справедливыми. При этом построение налоговой системы на базе единого налога рассматривалось чуть ли не как тест выполнения принципа справедливости налогообложения. Н.В. Миляков отмечает, что сторонники такой теории считали единый налог абсолютной панацеей, связывали его установление с исчезновением бедности, повышением оплата труда, искоренением кризисов перепроизводства, ростом хозяйства. Ученый обращает внимание на тесную связь политики и экономики, что проявлялось, например, в существовании в XVIII в. в Англии партии, девизом которой был единый налог на строения. [6] ${ }^{3}$

В. М. Пушкарева отмечает, что одной из первых теорий единого налога был единый акциз, целью которого было наложение налоговой обязанности на привилегированные классы общества [12]. ${ }^{4}$ Дальнейшее развитие теории единого налогообложения наблюдается во Франции («королевская десятина»). В. А. Лебедев отмечал, что в XVIII ст. известный французский ученый-экономист Себастьен Ле Претр де Вобан предложил коренное преобразование системы налогообложения. При этом аргументировалось несколько целей: упрощение налоговой системы; придание ей точности; обеспечение безвред-

\footnotetext{
3 [6] Миляков Н. В. Налоговое право: Учебник / Н.В. Миляков.- М.: ИНФРА-М, 2008.—383 с.-С. 360. ${ }^{4}$ [12] Пушкарева В. М. История финансовой мысли и политики налогов / В. М. Пушкарева.- М.: ИНФРА-М, 1996. - 192 с. - с. 113.
} 
ности и необременительности для граждан. По мнению В. А. Лебедева и С. Л. П. Вобана, существующие к тому времени во Франции налоги характеризовались неравномерностью, злоупотреблением ими со стороны власти.

Основным направлением указанного проекта в то время была идея достижения справедливости налогообложения относительно всех классов общества путем его осуществления простейшими и прямыми способами для достижения общего благосостояния [5]. ${ }^{1}$ По мнению С. Л. П. Вобана, десятина должна была взыскиваться с доходов от земледелия, промышленности и всех других источников доходов в размере от 5 до 10 процентов. Ученый был уверен, что налог должен быть удобным и пропорциональным. Вместе с тем, как отмечают И. Х. Озеров и И. И. Янжул, С. Л.П. Вобан не был последовательным. По мнению ученых он, проектируя замену одних существующих в то время налогов, сохранял другие: умеренный налог на соль, пошлину, налоги с оборота $[7,16] .^{2}$ Таким образом, навряд ли возможно назвать концепцию указанного французского ученого совершенной.

Одним из первых оформившихся экономических учений в Западной Европе было направление физиократов. Его глава Франсуа Кене (1694-1774) в работе «Общие принципы экономической политики земледельческого государства» (1758), в отличие от английской классической политэкономии, которая сосредоточила основное внимание на ана-

${ }^{1}$ [5] Лебедев В. А. Финансовое право / В. А. Лебедев.2-е изд.—СПб.: Тип. А. М. Вольфа, 1889. — 314 с.—С. 15

$2[7,16]$ Озеров И.Х. Основы финансовой науки / И.Х. Озеров.- Вып.1: Учение об обыкновенных доходах. - М.: Тип. И. Д. Сытина, 1908. - 544 с. - С. 73; Янжул И. И. Основные начала финансовой науки: Учение о государственных доходах / И.И. Янжул.СПб., 1899.-508 с.- С. 249. лизе промышленного производства, сделал объектом своего исследования земледелие. Впрочем, зарождаться эта идея начала еще в конце XVII ст. в произведениях по экономическим вопросам английского философа Д. Локка. В. А. Лебедев, анализируя произведения Д. Локка, отмечал, что, по его мнению, непосредственно должен облагаться налогом тот объект, из которого народ получает свои средства. В государствах, где главным богатством выступала земля, все налоги в конечном результате переводились на поземельный доход. Поэтому вместо многообразия налогов, по мнению Д. Локка, можно установить один - поземельный [5]. ${ }^{3}$

Немного позднее Франсуа Кене объявил единственной производительной силой отрасль земледелия, поскольку промышленность не дает чистой прибавки к доходу. Одно из центральных мест в экономической теории физиократов занимает учение о «чистом», или прибавочном, продукте. В противоположность меркантилистам физиократы перенесли вопрос о происхождении прибавочного продукта из области обращения в область материального производства. Как отмечает Н. В. Миляков, физиократы под «чистым» продуктом понимали избыток продукции, полученный в земледелии, над издержками производства. [6] ${ }^{4}$ Таким образом, одним из самых ранних видов единого налога был налог на земельную ренту. Физиократы считали, что все богатство сосредоточено в земле и проистекает из земли. Поэтому, по их мнению, надо было установить единый налог на земельную ренту, как на единственный источник доходов. Следовательно, платить

\footnotetext{
${ }^{3}$ [5] Лебедев В.А. Финансовое право / В. А. Лебедев.2-е изд.- СПб.: Тип. А. М. Вольфа, 1889. - 314 с.— С. 95.

4 [6] Миляков Н. В. Налоговое право: Учебник / Н.В. Миляков.—М.: ИНФРА-М, 2008.—383 с.—С. 360.
} 


\section{Налоги и налогообложение - №1(115) • 2014}

этот налог должны были только землевладельцы. В качестве основы для установления единого налога предлагалась идея «всеобщности земли». «Земля есть дар Божий, она должна принадлежать всем. Более того, все богатства происходят от земли. А поскольку в действительности земля принадлежит конкретным людям, то они как обладатели единственного источника богатства должны платить единый налог». [6] ${ }^{1}$

На территории современной Украины идея единого налога была впервые внедрена на практике в начале 20 -х годов ХХ ст. в виде единого натурального налога на продукты сельскохозяйственного производства. В тот исторический период в СССР, составной частью которого была Украина, введение уплаты единого натурального налога было обусловлено наличием многочисленных налогов на отдельные виды сельскохозяйственной продукции, плательщиками которых было сельское население. Это сдерживало развитие сельского хозяйства. Единый натуральный налог вводился в общеобязательном порядке для всего сельского населения вместо всех существующих к тому времени натуральных налогов.

На законодательном уровне взыскание единого налога впервые было закреплено декретом ВЦИК и РНК от 17 марта 1922 г. [2]. ${ }^{2}$ Однако единый натуральный налог окончательно не решил проблемы многочисленности налогов с крестьян, что препятствовало определению их доходов и расходов в полном объеме. Также, уменьшалась возможность дифференциации налогообложения на основе принципа про-

\footnotetext{
${ }^{1}$ [6] Миляков Н. В. Налоговое право: Учебник / Н.В. Миляков.- М.: ИНФРА-М, 2008.—383 с.—С. 360. 2 [2] Декрет ВЦИК «О едином натуральном налоге» от 17 марта 1922 г. // Сборник Указов РСФСР. - 1922.№ 25.- Ст. 284.
}

грессии, что обусловило принятие 10 мая 1923 г. ВЦИК Декрета о едином сельскохозяйственном налоге. Этот платеж объединял в себе единый натуральный налог, трудовой и гужевой налог, подворно-денежный, общеобщественный (в части налогообложения крестьян) и некоторые местные налоги [1]. ${ }^{3}$ Сначала единый сельскохозяйственный налог платился частично натурой, а частично деньгами, причем крестьяне могли сами избирать форму уплаты, а с 1924 года исключительно деньгами.

После распада СССР существенно изменился политико-экономический режим, возникла потребность в развитии предпринимательской деятельности, что на фоне общего экономического упадка сопровождалось многочисленными трудностями в налогообложении. Продолжительное время в Украине взыскание единого налога основывалось на П. 4 Переходных положений Конституции Украины, который наделял Президента Украины на протяжении трех лет после вступления в силу Конституции Украины полномочиями издавать указы по экономическим вопросам, не урегулированных законами [4]. Учитывая указанную процедуру, Президент Украины вместе с изданием Указа «Об упрощенной системе налогообложения, учета и отчетности субъектов малого предпринимательства» [10] ${ }^{5}$ в 1998 году одновременно подал в Верховной Рады Украины законопроект «Об упрощенной системе налогообложения, учета и отчетности субъектов малого пред-

\footnotetext{
3 [1] Декрет ВЦИК «О едином сельскохозяйственном налоге» от 10 мая 1923 г. // Сборник Указов РСФСР.1923.— № 42.— Ст. 451.

${ }^{4}$ [4] Конституція України // Відомості Верховної Ради України.-1996.— № 30.- Ст. 141.

5 [10] Про спрощену систему оподаткування, обліку та звітності суб'єктів малого підприємництва: Указ Президента України від 03.07.1998 р. № 727/98 // Офіційний вісник України. — 1998.— № 27.—Ст. 975.
} 
принимательства», [11] $]^{1}$ который на протяжении тридцати календарных дней с момента его представления Верховная Рада Украины не приняла, но и не отклонила представленный законопроект. В результате Указ вступил в действие и регулировал взыскание единого налога до 2012 года, когда была внедрена новая модель единого налога, закрепленная в соответствующем разделе Налогового кодекса Украины. [8] ${ }^{2}$

Вместе с тем, принятие первоначального варианта Налогового кодекса Украины в 2010 году было связано с многочисленными общественными колебаниями, вызванными спецификой именно правового регулирования единого налога, предложенного к тому времени. Глава «Упрощенная система налогообложения, учета и отчетности» раздела XIV Налогового кодекса от 02.12.2010 г. № 2755VI фигурировала также в первом проекте Налогового кодекса Украины, который был принят за основу 17 июня 2010 года. Этот законопроект подвергся жесткой критике относительно упрощенной системы. Новый этап принятия Налогового кодекса Украины начался 7 октября, когда его доработанный проект был принят за основу постановлением Верховной Рады № 2593-VI. Сначала Налоговый кодекс был принят 18 ноября, но 30 ноября Президент после массовых акций протеста накладывает на него вето.

Второго декабря Верховная Рада повторно принимает Налоговый кодекс с учетом пожеланий Президента, а 3 декабря кодекс подписывает глава государства. Места для упрощенной системы налогообложения в окон-

\footnotetext{
${ }^{1}$ [11] Про спрощену систему оподаткування, обліку та звітності суб'єктів малого підприємництва: Проект закону України одержаний Верховною Радою України 03.07.1998 p.

2 [8] Податковий кодекс України від 02.12.2010 р. № 2755VI // Відомості Верховної Ради України. - 2011. № 13-17.- Ст. 112.
}

чательном варианте принятого в 2010 году Налогового кодекса Украины не нашлось. Согласно разделу XIV «Специальные налоговые режимы», глава 1 была изъята. Вместе с тем в разделе $\mathrm{XX}$ «Переходные положения» определено, что с 1 января 2011 г. до внесения изменений в раздел XIV Налогового кодекса Украины действующим является Указ Президента Украины «Об упрощенной системе налогообложения, учета и отчетности субъектов малого предпринимательства» от 03.07.98 г. № 727. [10] $]^{3}$

Новый этап развития правого регулирования единого налога датируется маем 2011 г., когда был подготовлен и представлен на рассмотрение Верховной Рады Кабинетом министров Украины Законопроект № 8521 . В конце октября этот Закон был принят, однако Президент возвратил его со своими замечаниями. Последние преимущественно касались не самой упрощенной системы, а внедрения нулевой ставки при налогообложении налогом на добавленную стоимость операций по экспорту зерновых культур. Окончательно указанный Закон был принят 4 ноября 2011 г., но начала действовать новая модель единого налога только с 2012 года.

Не вдаваясь в подробности заметим, что новая модель единого налога имеет значительное количество преимуществ перед предыдущей. Количество групп (фактически вариантов применения упрощенной системы в форме единого налога) было увеличено сначала до четырех, а со временем - до шести. Также были увеличены объемы дохода и количество наемных работников. Эти два критерия как раз и определяют право применения единого налога вообще и диффе-

\footnotetext{
3 [10] Про спрощену систему оподаткування, обліку та звітності суб'єктів малого підприємництва: Указ Президента України від 03.07.1998 р. № 727/98 // Офіційний вісник України._ 1998.— № 27.— Ст. 975.
} 


\section{Налоги и налогообложение - №1(115) • 2014}

ренцируют возможность нахождения на той или другой группе. Безусловным достоянием новой модели единого налога стало внедрение бессрочных свидетельств. Теперь нет необходимости каждый год переоформлять эти свидетельства, что раньше на практике вызвало немалые трудности. Подводя итог изложенному следует заключить, что в целом наблюдается эволюционное развитие правового регулирования единого налога в Украине, который является, пожалуй, самым значимым специальным налоговым режимом.

\section{Библиография}

1. Декрет ВЦИК «О едином сельскохозяйственном налоге» от 10 мая 1923 г. // Сборник Указов РСФСР.— 1923.— № 42.— Ст. 451.

2. Декрет ВЦИК «О едином натуральном налоге» от 17 марта 1922 г. // Сборник Указов РСФСР. - 1922. - № 25.- Ст. 284.

3. Исаев А. Л. Начала политической экономии / Исаев А. Л.- СПб.: Тип. Стасюлевича, 1896. - $728 \mathrm{c}$.

4. Конституція України // Відомості Верховної Ради України. - 1996. — № 30. - Ст. 141.

5. Лебедев В. А. Финансовое право / В. А. Лебедев. - 2-е изд.- СПб.: Тип. А. М. Вольфа, 1889. - $314 \mathrm{c}$.

6. Миляков Н. В. Налоговое право: Учебник / Н. В. Миляков. - М.: ИНФРА-М, 2008. - 383 с.

7. Озеров И.Х. Основы финансовой науки / И.Х. Озеров. - Вып.1: Учение об обыкновенных доходах. - М.: Тип. И. Д. Сытина, 1908. - 544 с.

8. Податковий кодекс України від 02.12.2010 р. № 2755-VI // Відомості Верховної Ради України. - 2011.— № 13-17.—Ст. 112.

9. Пожидаєва М. А. Правове регулювання єдиного податку для суб'єктів малого підприємництва: Дис... канд. юрид. наук: 12.00.07 / М. А. Пожидаєва; НАН України. Ін-т держави і права ім. В. М. Корецького.- К., 2005.— 204 с.

10. Про спрощену систему оподаткування, обліку та звітності суб'єктів малого підприємництва: Указ Президента України від 03.07.1998 р. № 727/98 // Офіційний вісник України.— 1998. — № 27.- Ст. 975.

11. Про спрощену систему оподаткування, обліку та звітності суб'єктів малого підприємництва: Проект закону України, одержаний Верховною Радою України 03.07.1998 p.

12. Пушкарева В. М. История финансовой мысли и политики налогов / В. М. Пушкарева.- М.: ИНФРА-М, 1996. - $192 \mathrm{c}$.

13. Селигман Э. Этюды по теории обложения / Селигман Э., Стурм Р.-СПб.: Тип. Правда, 1908.-200 c.

14. Соколов А. А. Теория налогов / А. А. Соколов. М.: ООО «ЮрИнфоР-Пресс», 2003. - С. 121.

15. Финансы и налоги: очерки теории и политики.- М.: Статут (в серии «Золотые страницы финансового права России»), 2004.— Т. 4.-618 с.

16. Янжул И.И. Основные начала финансовой науки: Учение о государственных доходах / И. И. Янжул.-СПб., 1899.—508 с.

17. Деньга С.Н.. Совершенствование актива балансов предприятий Украины//Финансовое право и управление, 2013-1.

18. Воронова Л. К.. Новое законодательство Украины о бюджетных расходах как третьей стадии бюджетного процесса//Финансовое право и управление, 2014-1. 


\section{References (transliterated)}

1. Dekret VTsIK «O edinom sel'skokhozyaistvennom naloge» ot 10 maya 1923 g. // Sbornik Ukazov RSFSR. - 1923. - № 42. - St. 451.

2. Dekret VTsIK «O edinom natural'nom naloge» ot 17 marta 1922 g. // Sbornik Ukazov RSFSR.1922. — № 25. - St. 284.

3. Isaev A. L. Nachala politicheskoi ekonomii / Isaev A. L. — SPb.: Tip. Stasyulevicha, 1896. — $728 \mathrm{~s}$.

4. Konstitutsiya Ukraïni // Vidomosti Verkhovnoï Radi Ukraïni._ 1996. — № 30.— St. 141.

5. Lebedev V.A. Finansovoe pravo / V. A. Lebedev. - 2-e izd.— SPb.: Tip. A. M. Vol'fa, 1889.$314 \mathrm{~s}$.

6. Milyakov N. V. Nalogovoe pravo: Uchebnik / N. V. Milyakov.— M.: INFRA-M, 2008.— 383 s.

7. Ozerov I. Kh. Osnovy finansovoi nauki / I. Kh. Ozerov. - Vyp.1: Uchenie ob obyknovennykh dokhodakh. - M.: Tip. I. D. Sytina, 1908. - 544 s.

8. Podatkovii kodeks Ukraïni vid 02.12.2010 r. № 2755-VI // Vidomosti Verkhovnoï Radi Ukraïni. 2011. — № 13-17. — St. 112.

9. Pozhida€va M. A. Pravove regulyuvannya €dinogo podatku dlya sub'€ktiv malogo pidpri€mnitstva: Dis... kand. yurid. nauk: 12.00.07 / M. A. Pozhida€va; NAN Ukraïni. In-t derzhavi i prava im. V. M. Korets'kogo. - K., 2005. - 204 s.

10. Pro sproshchenu sistemu opodatkuvannya, obliku ta zvitnosti sub'€ktiv malogo pidpri€mnitstva: Ukaz Prezidenta Ukraïni vid 03.07.1998 r. № 727/98 // Ofitsiinii visnik Ukraïni._ - 1998. № 27. - St. 975.

11. Pro sproshchenu sistemu opodatkuvannya, obliku ta zvitnosti sub'€ktiv malogo pidpriєmnitstva: Proekt zakonu Ukraïni, oderzhanii Verkhovnoyu Radoyu Ukraïni 03.07.1998 r.

12. Pushkareva V.M. Istoriya finansovoi mysli i politiki nalogov/ V. M. Pushkareva. - M.: INFRA-M, 1996. - $192 \mathrm{~s}$.

13. Seligman E. Etyudy po teorii oblozheniya / Seligman E., Sturm R. — SPb.: Tip. Pravda, 1908. $200 \mathrm{~s}$.

14. Sokolov A. A. Teoriya nalogov / A. A. Sokolov. M.: OOO «YurInfoR-Press», 2003. — S. 121.

15. Finansy i nalogi: ocherki teorii i politiki. - M.: Statut (v serii «Zolotye stranitsy finansovogo prava Rossii»), 2004.- T. 4.- 618 s.

16. Yanzhul I. I. Osnovnye nachala finansovoi nauki: Uchenie o gosudarstvennykh dokhodakh / I. I. Yanzhul. - SPb., 1899. - 508 s.

17. Den'ga S.N.. Sovershenstvovanie aktiva balansov predpriyatii Ukrainy//Finansovoe pravo i upravlenie, 2013-1.

18. Voronova L.K.. Novoe zakonodatel'stvo Ukrainy o byudzhetnykh raskhodakh kak tret'ei stadii byudzhetnogo protsessa//Finansovoe pravo i upravlenie, 2014-1. 